\title{
Effect modification by workplace social capital on the association between depression and workplace and family stress: the Japanese civil servant study
}

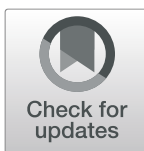

Nobue Nakahori ${ }^{1,2^{*}}$, Michikazu Sekine ${ }^{2}$, Takashi Tatsuse ${ }^{2}$ and Masaaki Yamada ${ }^{2}$

\begin{abstract}
Background: Mental health problems among workers have become an issue in Japan. The working environment for civil servants is becoming excessively stressful, and there is a need to prevent the onset of depression. In addition to stress at the workplace and at home, social capital has been reported as a factor associated with depression. This study examined whether workplace social capital reduces the association between depression and work-related stress or depression and home-related stress.

Methods: A total of 3015 Japanese civil servants (1867 men and 1148 women) from Toyama Prefecture were included in this study. Data on depression and workplace social capital, work status, work stress, work-life balance, and physical health were collected.

Results: The odds ratio for depression was higher for both men and women with low workplace social capital. For those with low workplace social capital, the adjusted odds ratio for depression was 2.93 (95\% confidence interval $[\mathrm{Cl}], 2.16-3.98)$ for men and $2.46(95 \% \mathrm{Cl}, 1.74-3.49)$ for women. After adjusting for workplace social capital, the associations between depression and low job position, low job support, and moderate family-to-work conflict declined in men and were no longer significant. For women, the strength of the association between depression and unmarried status along with moderate control at work decreased and also lost significance. When the ORs for depression were stratified by high and low workplace social capital and compared with the ORs before stratification, the ORs for depression of long working hours and work-to-family conflict increased for both men and women in the low workplace social capital group.
\end{abstract}

Conclusions: Workplace social capital mitigated the effect of workplace and family stress leading to depression in both men and women.

Keywords: Depression, Gender, Japanese civil servants study, Workplace social capital

\footnotetext{
* Correspondence: n-nakahori@tsuruga-nu.ac.jp

${ }^{1}$ Faculty of Nursing Science, Tsuruga Nursing University, 78-2-1 Kizaki,

Tsuruga, Fukui 914-0814, Japan

${ }^{2}$ Department of Epidemiology and Health Policy, School of Medicine,

University of Toyama, 2630 Sugitani, Toyama, Toyama 930-0194, Japan
}

(C) The Author(s). 2021 Open Access This article is licensed under a Creative Commons Attribution 4.0 International License, which permits use, sharing, adaptation, distribution and reproduction in any medium or format, as long as you give appropriate credit to the original author(s) and the source, provide a link to the Creative Commons licence, and indicate if changes were made. The images or other third party material in this article are included in the article's Creative Commons licence, unless indicated otherwise in a credit line to the material. If material is not included in the article's Creative Commons licence and your intended use is not permitted by statutory regulation or exceeds the permitted use, you will need to obtain permission directly from the copyright holder. To view a copy of this licence, visit http://creativecommons.org/licenses/by/4.0/ The Creative Commons Public Domain Dedication waiver (http://creativecommons.org/publicdomain/zero/1.0/) applies to the data made available in this article, unless otherwise stated in a credit line to the data. 


\section{Background}

Suicide is the leading cause of death among workers in their twenties and thirties, second among those in their forties, and third or fourth among those in their fifties [1]. About $97 \%$ of suicides were reported to be due to a diagnosed mental disorder [2], indicating that mental health issues are a significant factor in suicide among workers. About 20\% of workers annually take a leave of absence or resign due to mental health issues [3].

The work environment for civil servants is becoming increasingly difficult. Salaries are steadily declining compared to several years ago, the number of new hires is being scaled back, and positions vacated by retirees are being cut. At the same time, the workload is becoming more diverse and complex and the systems and public services that are in place are rarely reduced, meaning that the amount of work per person increases every year.

Under these circumstances, more and more civil servants suffer physical and mental health problems, such as depression, which can lead to suicide. Longterm sick leave among civil servants in 2019 was 2700 out of 100,000, of which $60 \%$ was due to "mental and behavioral disorders" [4]. As the size of the civil service workforce declines through attrition due to retirement, resignations, or suicides due to mental health issues, the increased stress on public services can affect the quality of services offered and the quality of life of the residents. It is a vicious cycle, increasing the workload on those workers who remain and negatively affecting the productivity of the entire workplace.

In order to avoid this cycle, it is important that mental health problems among workers are recognized as early as possible and efforts made to address the situation before it results in serious consequences. Previous studies have reported additional causes of depression among workers beyond overwork, including job stress, impaired work-life balance, and physical health [5]. Other reported causes of workplace depression include unpleasant bosses, unequal work environment [6-8], and dissatisfaction with work $[9,10]$. Similarly, some people are able to work in busy departments and maintain their mental health and others are not, despite similar workloads. When we considered these differences, we wondered if social capital in the workplace, which can be described as good teamwork, had an effect in addition to personal qualities. There are several types of social capital, which reportedly to enhance physical and mental health as well as work engagement [11-14]. In order to maintain mental health, we thought that workplace social capital (defined in this study as understanding and acknowledging each other in the workplace) would be important.

Low workplace social capital has been reportedly associated with mental health issues around the world [15-
19]. However, few have examined whether workplace social capital is independently associated with depression after adjusting for work-life condition, job stress, worklife balance, and physical health. There is a lack of research evaluating the effect modification of whether workplace social capital reduces the association between depression and these stressors. It is also important to understand how gender differences in physical and mental health [20-23] and disparities in sleep duration impact an individual's response to these stressors and how workplace social capital can change the association between these stressors and depression [24, 25].

This study examined whether workplace social capital reduces the association between depression and worklife condition, job stress, work-life balance, and physical health, accounting for gender differences.

\section{Methods}

This study has a cross-sectional study design.

\section{Study subjects}

The Japanese Civil Service Study is an international collaboration with the British Civil Service Study (Whitehall Study) and has been conducted regularly since 1998 [24]. The subjects were all civil servants in 1 prefecture in central Japan. A total of 3997 persons responded to a questionnaire survey conducted in 2014. After excluding those who were not between the ages of 20 and 59 years old and those who had 1 or more missing responses to the survey items required for analysis, a total of 3015 respondents (1867 men and 1148 women) were included in the final analysis. The reason for excluding individuals in the age groups under 20 and over 60 is that they are small in number, and those over 60 may have different work experience, such as re-employment after retirement.

\section{Measures \\ Questionnaire}

The items in the questionnaire were selected primarily from the Whitehall Study and reviewed by Whitehall researchers. The survey items included demographics (age and gender), depression (CES-D scores), workplace social capital, work-life condition (marital status, job position, work hours, shift work), job stress (control at work, demand at work, job support), work-life balance (family-to-work conflict, work-to-family conflict), and physical health (sleep duration and presence of longstanding illness). Variables other than workplace social capital were selected because a previous study on the same subjects [5] reported a significant association with depression.

Work-life condition included marital status, job position, work hours, and shift work. Marital status was 
categorized as "married" or "unmarried"; job position was categorized as "low grade," "middle grade," or "high grade"; work hours was categorized as " $<9$ hours ," "9$11 \mathrm{~h}$," or " $>11 \mathrm{~h}$ "; and shift work was categorized as "yes" or "no."

Karasek's model [26] of job discretion, job demands, and job support was used as a rating scale for job stress. The model consisted of 25 items ( 15 items on control at work, 4 on job demands, and 6 on social support), and responses were selected from 4 options (common, sometimes, rarely, and never). Control at work was investigated with the following 15 items: (1) Do you have a choice in deciding how you do your job? (2) Do you have a choice in deciding what you do at work? (3) Others make decisions concerning my work. (4) I have a good deal of say in decisions about work. (5) I have a say in my own work speed. (6) my working time can be flexible. (7) I can decide when to take a break. (8) I have a say in choosing who I work with. (9) I have a great deal of say in planning my work environment. (10) Do you have to do the same thing over and over again? (11) Does your job provide you with a variety of interesting things? (12) Is your job boring? (13) Do you have the possibility of learning new things through your work? (14) Does your work demand a high level of skill or expertise? (15) Does your job require you to take the initiative? Job demands was investigated with the following 4 items: (1) Do you have to work very fast? (2) Do you have to work very intensively? (3) Do you have enough time to do everything? (4) Do different groups at work demand things from you that you think are hard to combine? Social support was investigated with the following 6 items: (1) How often do you get help and support from your colleagues? (2) How often are your colleagues willing to listen to your work-related problems? (3) How often do you get help and support from your immediate superior? (4) How often is your immediate superior willing to listen to your problems? (5) Do you get sufficient information from line management (your superiors)? (6) Do you get consistent information from line management (your superiors)? Responses are scored from 0 (often) to 3 (rarely), with higher total scores denoting more stressful situations. The total score was divided into 3 quartiles for each of the discretionary, demanding, and supportive aspects of the work, and then divided into 3 groups: "low," "medium," and "high."

The Family-Work Conflict questions were used to assess work-life balance, consisting of 8 items, 4 for Family-to-work conflict and 4 for Work-to-family conflict [27]. Responses were selected from 3 options (not at all, some, and often). Family-to-Work conflict was investigated with the following 4 items: (1) Family matters reduce the time you can devote to your job. (2) Family worries or problems distract you from your work.
(3) Family activities stop you from getting the amount of sleep you need to do your job well. (4) Family obligations reduce the time you need to relax or be yourself. Work-to-family Conflict was investigated with the following 4 items: (1) Your job reduces the amount of time you can spend with the family. (2) Problems at work make you irritable at home. (3) Your work involves a lot of travel away from home. (4) Your job takes so much energy you do not feel up to doing things that need attention at home. Responses were scored from 0 (never) to 2 (frequently), with higher total scores denoting situations with higher conflicts.

In terms of physical health, sleep duration was categorized as " $<6 h$," " $6-8 h$," and " $\geq 9 h$," and longstanding illness was measured by asking the respondents to answer the question, "Do you currently have a chronic disease or illness?" with two choices, "yes" or "no."

\section{Depression score}

The Center for Epidemiologic Studies Depression Scale (CES-D) was used as a measure of depression and is a highly valid and reliable test [28]. The CES-D consists of 20 items, of which 16 are negative-denoting the presence of symptoms of depression, such as depressive mood, physical symptoms, and interpersonal relationships-and 4 are positive-denoting the absence of symptoms of depression, such as positive mood. Respondents were asked to rate, on a scale of 1 to 4 , how frequently they experienced symptoms over the past week: none (1 point), $1-2$ days ( 2 points), $3-4$ days ( 3 points), or $\geq 5$ days (4 points). On the CES-D, a total score of $\geq 16$ suggested the presence of depression; however, our study used a score of $\geq 19$ as suggestive of "depression" and $\leq 18$ as "not depressed," based on previous studies of Japanese civil servants [29].

\section{Workplace social capital}

Workplace social capital refers to 3 items in the standard version of the New Brief Job Stress Questionnaire [30]: "In our workplaces, we are willing to work together"; "In our workplaces, we understand and acknowledge each other"; and "In our workplaces, we are able to share work-related information." In the short version, workplace social capital refers to the item "In our workplaces, we understand and acknowledge each other." Responses are selected from 4 options: strongly agree (1 point), agree ( 2 points), disagree (3 points), or strongly disagree (4 points). In the current study, a shortened version was adopted, and respondents were classified as "high" if they answered "strongly agree" or "agree" to the question of whether they had social capital in the workplace, and "low" if they answered "disagree" or "strongly disagree." The standard version of the New Brief Job 
Stress Questionnaire and its short version have been validated for reliability and validity $[31,32]$.

\section{Statistical analysis}

The proportional differences between subjects' characteristics were compared on the basis of gender using the Chi square $\left(x^{2}\right)$ test. Age-adjusted Mantel-Haenszel tests were conducted to examine the relationship between workplace social capital and each variable, and the results were compared for each gender. In order to examine the association between workplace social capital and depression-related factors, the proportion of each depression-related factor in the high and low workplace social capital groups was compared on the basis of gender using the $x^{2}$ test. Logistic regression analyses were conducted for both genders, with the presence of depression as the dependent variable and each item as an independent variable. Several multivariate models [33] were constructed to examine how workplace social capital affects the association between depression and work-life condition, job stress, work-life balance, and physical health. The age-adjusted OR for depression was calculated first for each variable, after which the remaining variables (work-life condition, job stress, work-life balance, and physical health) were adjusted in order to calculate the OR and 95\% CI, respectively, between depression and each variable. Effect modifications by workplace social capital on the association between depression and each variable was examined. The ageadjusted ORs for depression were calculated by logistic regression analysis, and the ORs of the subjects before stratification and the high and low groups after stratification by workplace social capital were compared. SPSS ver.23 was used for all analyses, with $5 \%$ being the significance level.

\section{Results}

Table 1 shows the characteristics of the subjects according to gender. The mean age was 44.95 (SD 9.56) years for men and 38.30 (SD 10.70) years for women. The mean CES-D score was 13.50 (SD 8.39) for men and 15.39 (SD 8.75) for women. The mean workplace social capital was 2.98 (SD 0.68) for men and 2.91 (SD 0.68) for women. There was a significant difference between men and women in all variables. Working hours were longer for women and a higher percentage of women worked in shifts. Men were more likely to have more control at work, and women were more likely to have high job demands. Men were less likely to be supported at work. Family-to-work conflict and work-to-family conflict were higher for women. Women were more likely to sleep $<6 \mathrm{~h}$ and men were more likely to have longstanding illnesses. A higher percentage of women reported having little or no workplace social capital.
Women were more likely to have higher levels of depression.

Table 2 shows the association between depression and age-adjusted workplace social capital by gender. The variables that were significantly associated with lack of workplace social capital among men were low job position, low control at work, high job demands, low job support, high family-to-work conflict, high work-tofamily conflict, and the presence of longstanding illness. The variables that were significantly associated with lack of workplace social capital among women were unmarried status, low control at work, high work demands, low job support, high work-to-family conflict, high family-to-work conflict, and less sleep ( $<6 \mathrm{~h})$.

Table 3 shows the association between depression and workplace social capital among men. The OR for depression was higher for low workplace social capital. The adjusted OR for depression with low workplace social capital was 2.93 (95\% confidence interval [CI] 2.16-3.98) (model 5). After adjusting for workplace social capital, the strength of the associations between depression and low grade job position (model 1), low job support (model 2), and moderate family-to-work conflict (model3) decreased and also lost significance. The associations between depression and low control at work (model 2), high family-to-work conflict, and moderate and high work-to-family conflict (model 3) were reduced. After adjusting for all variables, significant associations with depression were found for unmarried, low and moderate control at work, high familyto-work conflict, moderate and high work-to-family conflict, sleep of $<6 \mathrm{~h}$, and presence of longstanding illness, while the associations between depression and long work hours and high work demands disappeared (model 5).

Table 4 shows the association between workplace social capital and depression among women. The OR for depression was higher for low workplace social capital. The adjusted OR of workplace social capital to depression was 2.46 (95\% CI 1.74-3.49) (model 5). After adjusting for workplace social capital, the strength of the associations between depression and unmarried status (model 1) and moderate control at work (model 2) were reduced and lost significance. The associations between depression and long work hours (model 1), low control at work, low and moderate job support (model 2), high family-to-work conflict, moderate and high work-tofamily conflict, and sleep of $<6 \mathrm{~h}$ were reduced. After adjusting for all variables, significant associations with depression were found for unmarried, low and moderate job support, high family-to-work conflict, moderate and high work-to-family conflict, and sleep periods of $<6 \mathrm{~h}$, while the associations between depression and long work hours, shift work, low control at work, moderate and high work demands, and longstanding illness disappeared (model 5). 
Table 1 Characteristics of subjects by gender

\begin{tabular}{|c|c|c|c|}
\hline & $\operatorname{Men}(n=1867)$ & Women $(n=1148)$ & $x^{2} p$-value \\
\hline & $\%$ & $\%$ & \\
\hline Age & & & $<0.001$ \\
\hline $20-29$ & 9.2 & 26.8 & \\
\hline $30-39$ & 17.3 & 28.3 & \\
\hline $40-49$ & 36.8 & 25.0 & \\
\hline $50-59$ & 36.7 & 19.9 & \\
\hline Marital status & & & $<0.001$ \\
\hline Married & 80.2 & 55.7 & \\
\hline Unmarried & 19.8 & 44.3 & \\
\hline Job position & & & $<0.001$ \\
\hline Low grade & 56.0 & 86.4 & \\
\hline Middle grade & 26.4 & 10.7 & \\
\hline High grade & 17.6 & 2.9 & \\
\hline Work hours & & & $<0.001$ \\
\hline$<9 h$ & 65.1 & 56.2 & \\
\hline $9-11 \mathrm{~h}$ & 26.4 & 34.6 & \\
\hline$>11 \mathrm{~h}$ & 8.5 & 9.2 & \\
\hline Shift work & & & $<0.001$ \\
\hline Yes & 8.1 & 43.9 & \\
\hline No & 91.9 & 56.1 & \\
\hline Control at work & & & $<0.001$ \\
\hline Low & 26.6 & 33.0 & \\
\hline Intermediate & 32.1 & 35.9 & \\
\hline High & 41.3 & 31.1 & \\
\hline Demand at work & & & $<0.001$ \\
\hline Low & 34.3 & 28.1 & \\
\hline Intermediate & 33.2 & 30.9 & \\
\hline High & 32.5 & 40.9 & \\
\hline Support at work & & & $<0.001$ \\
\hline Low & 27.2 & 21.4 & \\
\hline Intermediate & 37.9 & 35.1 & \\
\hline High & 34.9 & 43.5 & \\
\hline Family-to-work conflict & & & $<0.001$ \\
\hline Low & 47.2 & 43.6 & \\
\hline Intermediate & 15.5 & 12.2 & \\
\hline High & 37.2 & 44.3 & \\
\hline Work-to-family conflict & & & $<0.001$ \\
\hline Low & 32.2 & 24.0 & \\
\hline Intermediate & 36.6 & 34.5 & \\
\hline High & 31.1 & 41.6 & \\
\hline Sleep hours & & & $<0.001$ \\
\hline$<6 \mathrm{~h}$ & 15.2 & 20.6 & \\
\hline $6-8 \mathrm{~h}$ & 84.1 & 78.5 & \\
\hline$\geqq 9 h$ & 0.7 & 0.9 & \\
\hline
\end{tabular}


Table 1 Characteristics of subjects by gender (Continued)

\begin{tabular}{llll}
\hline & $\begin{array}{l}\text { Men }(\boldsymbol{n}=\mathbf{1 8 6 7}) \\
\%\end{array}$ & $\begin{array}{l}\text { Women }(\boldsymbol{n = 1 1 4 8 )} \\
\%\end{array}$ \\
\hline $\begin{array}{l}\text { Longstanding illness } \\
\text { Yes }\end{array}$ & 36.5 & 24.0 & $<0.001$ \\
No & 63.5 & 76.0 \\
Workplace social capital & & \\
High & 82.0 & 77.8 \\
Low & 18.0 & 22.2 \\
Depression & & \\
$\quad$ Yes & 23.0 & 30.5 \\
No & 77.0 & 69.5 \\
\hline
\end{tabular}

Table 5 shows the effect modification by workplace social capital in the association between depression and work-life condition, job stress, work-life balance, and physical health. In men, after stratification with workplace social capital, the variables with higher odds ratios for depression in the lower workplace social capital group were unmarried status, $9-11 \mathrm{~h}$ of work, low/moderate job control, high work-to-family conflict, $<6 \mathrm{~h}$ of sleep, and longstanding illness. In women, after stratification with workplace social capital, the variables with higher odds ratios for depression in the low workplace social capital group were $\geq 9-11$ work hours, moderate /

Table 2 Age-adjusted workplace social capital differences in depression related factors by gender

\begin{tabular}{|c|c|c|c|c|}
\hline & \multirow[b]{2}{*}{ Depression-related factors } & \multicolumn{2}{|c|}{ Workplace social capital } & \multirow[b]{2}{*}{$x^{2} p$-value } \\
\hline & & High(\%) & Low(\%) & \\
\hline Men $(n=1867)$ & & $(n=1531)$ & $(n=336)$ & \\
\hline Marital status & Unmarried & 19.7 & 20.5 & 0.490 \\
\hline Job position & Low & 54.2 & 64.3 & $<0.001$ \\
\hline Work hours & Long (>9 h) & 34.9 & 34.8 & 0.894 \\
\hline Shift work & Yes & 7.8 & 9.5 & 0.300 \\
\hline Control at work & Low & 23.6 & 40.2 & $<0.001$ \\
\hline Demand at work & High & 30.6 & 41.1 & $<0.001$ \\
\hline Support at work & Low & 21.5 & 53.3 & $<0.001$ \\
\hline Family-to-work conflict & High & 33.9 & 52.4 & $<0.001$ \\
\hline Work-to-family conflict & High & 28.2 & 44.6 & $<0.001$ \\
\hline Sleep hours & Short $(<6 h)$ & 14.4 & 18.8 & 0.079 \\
\hline Longstanding illness & Yes & 35.5 & 41.4 & 0.031 \\
\hline Women $(n=1148)$ & & $(n=893)$ & $(n=255)$ & \\
\hline Marital status & Unmarried & 42.9 & 49.0 & 0.002 \\
\hline Job position & Low & 86.0 & 87.8 & 0.273 \\
\hline Work hours & Long (>9 h) & 43.0 & 46.7 & 0.311 \\
\hline Shift work & Yes & 43.0 & 47.1 & 0.148 \\
\hline Control at work & Low & 28.0 & 50.6 & $<0.001$ \\
\hline Demand at work & High & 38.9 & 48.2 & 0.010 \\
\hline Support at work & Low & 14.3 & 46.3 & $<0.001$ \\
\hline Family-to-work conflict & High & 42.8 & 49.4 & 0.167 \\
\hline Work-to-family conflict & High & 38.2 & 53.3 & $<0.001$ \\
\hline Sleep hours & Short $(<6 h)$ & 18.4 & 28.6 & 0.001 \\
\hline Longstanding illness & Yes & 24.0 & 24.3 & 0.886 \\
\hline
\end{tabular}

The percentages in the table show how much depression-related factors account for the high and low workplace social capital groups 
Table $\mathbf{3}$ The association between workplace social capital and depression in men

\begin{tabular}{|c|c|c|c|c|c|c|c|}
\hline & $\begin{array}{l}\text { Prevalence of } \\
\text { depression(\%) }\end{array}$ & $\begin{array}{l}\text { Age-adjusted ORs } \\
(95 \% \mathrm{Cl})\end{array}$ & $\begin{array}{l}\text { Model } 1 \\
\text { Work life condition } \\
(95 \% \mathrm{Cl})\end{array}$ & $\begin{array}{l}\text { Model } 2 \\
\text { Job stress } \\
(95 \% \mathrm{Cl})\end{array}$ & $\begin{array}{l}\text { Model } 3 \\
\text { Work-life balance } \\
(95 \% \mathrm{Cl})\end{array}$ & $\begin{array}{l}\text { Model } 4 \\
\text { Physical health } \\
(95 \% \mathrm{Cl})\end{array}$ & $\begin{array}{l}\text { Model } 5 \\
\text { Full adjusted } \\
(95 \% \mathrm{Cl})\end{array}$ \\
\hline \multicolumn{8}{|c|}{ Workplace social capital } \\
\hline High & 17.6 & 1.00 & 1.00 & 1.00 & 1.00 & 1.00 & 1.00 \\
\hline Low & 47.3 & $4.14(3.25-5.38)$ & $4.11(3.18-5.33)$ & $3.39(2.58-4.46)$ & $3.42(2.60-4.49)$ & $4.12(3.18-5.33)$ & $2.93(2.16-3.98)$ \\
\hline \multicolumn{8}{|l|}{ Age } \\
\hline $20-29$ & 20.9 & $0.94(0.63-1.42)$ & $0.40(0.24-0.68)$ & $0.99(0.63-1.55)$ & $1.54(0.96-2.45)$ & $1.20(0.77-1.87)$ & $0.85(0.46-1.57)$ \\
\hline $30-39$ & 23.8 & $1.12(0.82-1.53)$ & $0.68(0.45-1.02)$ & $1.04(0.74-1.46)$ & $0.88(0.62-1.24)$ & $1.29(0.91-1.84)$ & $0.83(0.52-1.32)$ \\
\hline $40-49$ & 24.2 & $1.14(0.88-1.46)$ & $0.81(0.59-1.09)$ & $0.96(0.74-1.27)$ & $0.85(0.63-1.13)$ & $1.11(0.84-1.46)$ & $0.78(0.55-1.11)$ \\
\hline $50-59$ & 21.9 & 1.00 & 1.00 & 1.00 & 1.00 & 1.00 & 1.00 \\
\hline \multicolumn{8}{|l|}{ Marital status } \\
\hline Married & 21.2 & 1.00 & 1.00 & & & & 1.00 \\
\hline Unmarried & 30.3 & $1.92(1.44-2.56)$ & $1.93(1.43-2.62)$ & & & & $2.98(2.09-4.24)$ \\
\hline \multicolumn{8}{|l|}{ Job position } \\
\hline Low grade & 25.2 & $1.73(1.19-2.51)$ & $1.40(0.94-2.09)$ & & & & $1.01(0.64-1.59)$ \\
\hline Middle grade & 21.3 & $1.24(0.86-1.81)$ & $1.14(0.77-1.68)$ & & & & $0.86(0.56-1.32)$ \\
\hline High grade & 18.3 & 1.00 & 1.00 & & & & 1.00 \\
\hline \multicolumn{8}{|l|}{ Work hours } \\
\hline$<9 h$ & 20.3 & 1.00 & 1.00 & & & & 1.00 \\
\hline $9-11 \mathrm{~h}$ & 25.2 & $1.33(1.03-1.71)$ & $1.46(1.11-1.91)$ & & & & $0.96(0.70-1.32)$ \\
\hline$>11 \mathrm{~h}$ & 36.7 & $2.33(1.62-3.34)$ & $2.63(1.79-3.87)$ & & & & 1.43(0.89-2.29) \\
\hline \multicolumn{8}{|l|}{ Shift work } \\
\hline Yes & 28.5 & $1.38(0.95-2.00)$ & $1.47(0.99-2.19)$ & & & & $1.14(0.73-1.77)$ \\
\hline No & 22.5 & 1.00 & 1.00 & & & & 1.00 \\
\hline \multicolumn{8}{|l|}{ Control at work } \\
\hline Low & 35.3 & $3.17(2.41-4.16)$ & & $2.90(2.17-3.88)$ & & & $2.58(1.87-3.58)$ \\
\hline Intermediate & 23.5 & $1.78(1.35-2.35)$ & & $1.86(1.40-2.48)$ & & & $1.60(1.17-2.19)$ \\
\hline High & 14.7 & 1.00 & & 1.00 & & & 1.00 \\
\hline \multicolumn{8}{|l|}{ Demand at work } \\
\hline Low & 15.6 & 1.00 & & 1.00 & & & 1.00 \\
\hline Intermediate & 23.4 & $1.64(1.24-2.18)$ & & $1.82(1.35-2.45)$ & & & 1.35(0.96-1.90) \\
\hline High & 30.3 & $2.33(1.77-3.08)$ & & $2.43(1.81-3.27)$ & & & 1.15(0.80-1.66) \\
\hline \multicolumn{8}{|l|}{ Support at work } \\
\hline Low & 30.9 & $2.05(1.55-2.73)$ & & $1.19(0.86-1.6)$ & & & $1.09(0.76-1.54)$ \\
\hline Intermediate & 21.4 & $1.23(0.94-1.62)$ & & $1.05(0.78-1.40)$ & & & $1.03(0.75-1.41)$ \\
\hline High & 18.6 & 1.00 & & 1.00 & & & 1.00 \\
\hline \multicolumn{8}{|c|}{ Family-to-work conflict } \\
\hline Low & 11.7 & 1.00 & & & 1.00 & & 1.00 \\
\hline Intermediate & 17.9 & $1.70(1.18-2.46)$ & & & $1.22(0.83-1.80)$ & & 1.34(0.89-2.02) \\
\hline High & 39.4 & $5.16(3.97-6.71)$ & & & $2.95(2.21-3.93)$ & & $3.38(2.47-4.61)$ \\
\hline \multicolumn{8}{|c|}{ Work-to-family conflict } \\
\hline Low & 8.6 & 1.00 & & & 1.00 & & 1.00 \\
\hline Intermediate & 19.6 & $2.70(1.91-3.81)$ & & & $2.08(1.45-3.00)$ & & $1.98(1.35-2.92)$ \\
\hline High & 41.8 & $8.15(5.81-11.43)$ & & & $4.81(3.33-6.94)$ & & $4.51(2.96-6.86)$ \\
\hline
\end{tabular}


Table 3 The association between workplace social capital and depression in men (Continued)

\begin{tabular}{|c|c|c|c|c|c|c|c|}
\hline & & Age-adjusted ORs & Model 1 & Model 2 & Model 3 & Model 4 & Model 5 \\
\hline & $\begin{array}{l}\text { Prevalence of } \\
\text { depression(\%) }\end{array}$ & $(95 \% \mathrm{Cl})$ & $\begin{array}{l}\text { Work life condition } \\
(95 \% \mathrm{Cl})\end{array}$ & $\begin{array}{l}\text { Job stress } \\
(95 \% \mathrm{Cl})\end{array}$ & $\begin{array}{l}\text { Work-life balance } \\
(95 \% \mathrm{Cl})\end{array}$ & $\begin{array}{l}\text { Physical health } \\
(95 \% \mathrm{Cl})\end{array}$ & $\begin{array}{l}\text { Full adjusted } \\
(95 \% \mathrm{Cl})\end{array}$ \\
\hline Sleep ho & & & & & & & \\
\hline$<6 \mathrm{~h}$ & 39.6 & $2.63(2.01-3.45)$ & & & & $2.69(2.02-3.58)$ & $1.76(1.27-2.44)$ \\
\hline $6-8 \mathrm{~h}$ & 19.9 & 1.00 & & & & 1.00 & 1.00 \\
\hline$\geqq 9 \mathrm{~h}$ & 35.7 & $2.24(0.74-6.74)$ & & & & $1.93(0.60-6.21)$ & $1.65(0.44-6.12)$ \\
\hline Longstar & ness & & & & & & \\
\hline Yes & 28.7 & $1.81(1.43-2.29)$ & & & & $1.79(1.40-2.29)$ & $1.55(1.18-2.05)$ \\
\hline No & 19.7 & 1.00 & & & & 1.00 & 1.00 \\
\hline
\end{tabular}

Model 1 is adjusted for age, workplace social capital, and work life condition (marital status, job position, work hours, shift work)

Model 2 is adjusted for age, workplace social capital, and job stress (control at work, demand at work, support at work)

Model 3 is adjusted for age, workplace social capital, and work-life balance (family-to-work conflict, work-to-family conflict)

Model 4 is adjusted for age, workplace social capital, and physical health (sleep hours, longstanding illness)

Model 5 is adjusted for age, workplace social capital, work life condition, job stress, work-life balance, and physical health

high job requirements, and moderate/high work-tofamily conflict.

The Hosmer-Lemeshow test [32] validated the final models (Model 5 in Tables 3 and 4). The interaction terms of any 2 variables for work-life condition, job stress, work-life balance, and physical health did not add significantly to the models.

\section{Discussion}

In this study, workplace social capital was independently associated with depression among the adjusted variables (work-life condition, job stress, work-life balance, and physical health). Workplace social capital mitigated the associations between depression and stresses from work, home, or physical health in both men and women.

In terms of the association between workplace social capital and each variable, men and women who had low control at work, high work demands, low work support, and high work-to-family conflict felt significantly less workplace social capital. A high proportion of men who had a low job position or longstanding illness and women who were unmarried or sleeping less felt significantly less workplace social capital. This suggests that job stress and work-life balance are strongly related to workplace social capital in both men and women.

For both men and women, the OR of low workplace social capital for depression was significantly higher; (adjusted OR, 2.93 [95\% CI 2.16-3.98]) for men (adjusted OR, 2.46 [95\% CI 1.74-3.49]) for women. Previous studies have examined the association with depression in men, adjusting for variables of work-life condition, job stress, work-life balance, and physical health, and the OR between depression and low job status was still significant [34, 35]. However, when workplace social capital was added to those variables, as in the present study, the OR between depression and low job status was no longer significantly different. One of the factors that may have contributed to this finding was the fact that men held higher job statuses than women in this study. When one's position, or job status is higher, one has to organize the workplace and produce good work; however, with a lack of workplace social capital, it would be harder to improve work performance, which could increase depression.

Although workplace social capital and depression showed a strong association with workplace social capital, after adjusting for all variables, long hours and high job demands were no longer associated with depression for both men and women. This confirms the results of previous studies [6-8], which suggested that the cause of workplace depression is not overworked but rather the work environment. The associations with depression were reduced for both men and women, but significant associations remained including high family-to-work conflict, moderate and high work-to-family conflict, and sleep of $<6 \mathrm{~h}$.

Regardless of high or low workplace social capital, home-work/work-family conflict and short sleep duration were strongly associated with depression. The OR of depression to family-to-work conflict was not reduced, especially among women. A previous study reported poor work-life balance, especially among Japanese women [36]. This may be an indication that women play many central roles in the family, including child-rearing and household chores. The association between depression and longstanding illness remained significantly different for men, whereas the significance of the association with longstanding illness disappeared for women. We hypothesized that because men were older than women in the target population, physical health was more likely to affect mental health in men than in women in this study; thus expecting the percentage of people with longstanding illness to increase with age. In contrast, the association between depression and being 
Table 4 The association between workplace social capital and depression in women

\begin{tabular}{|c|c|c|c|c|c|c|c|}
\hline & & Age-adjusted ORs & Model 1 & Model 2 & Model 3 & Model 4 & Model 5 \\
\hline & $\begin{array}{l}\text { Prevalence of } \\
\text { depression(\%) }\end{array}$ & $(95 \% \mathrm{Cl})$ & $\begin{array}{l}\text { Work life condition } \\
(95 \% \mathrm{Cl})\end{array}$ & $\begin{array}{l}\text { Job stress } \\
(95 \% \mathrm{Cl})\end{array}$ & $\begin{array}{l}\text { Work-life balance } \\
(95 \% \mathrm{Cl})\end{array}$ & $\begin{array}{l}\text { Physical health } \\
(95 \% \mathrm{Cl})\end{array}$ & $\begin{array}{l}\text { Full adjusted } \\
(95 \% \mathrm{Cl})\end{array}$ \\
\hline Workplace social & | capital & & & & & & \\
\hline High & 24.0 & 1.00 & 1.00 & 1.00 & 1.00 & 1.00 & 1.00 \\
\hline Low & 53.3 & $3.80(2.83-5.11)$ & $3.69(2.73-4.99)$ & $2.85(2.06-3.94)$ & $3.39(2.47-4.65)$ & $3.38(2.73-4.96)$ & $2.46(1.74-3.49)$ \\
\hline Age & & & & & & & \\
\hline $20-29$ & 36.4 & $1.84(1.26-2.70)$ & $1.57(0.93-2.67)$ & $2.64(1.73-4.04)$ & $3.95(2.50-6.22)$ & $2.77(1.80-4.27)$ & $3.33(1.80-6.15)$ \\
\hline $30-39$ & 33.2 & $1.60(1.09-2.35)$ & $1.45(0.90-2.33)$ & $1.80(1.19-2.73)$ & $1.95(1.27-2.98)$ & $2.01(1.32-3.07)$ & $1.99(1.16-3.41)$ \\
\hline $40-49$ & 26.5 & $1.16(0.78-1.74)$ & $1.25(0.80-1.96)$ & $1.36(0.88-2.09)$ & $1.15(0.74-1.79)$ & $1.46(0.95-2.25)$ & $1.32(0.80-2.18)$ \\
\hline $50-59$ & 23.7 & 1.00 & 1.00 & 1.00 & 1.00 & 1.00 & 1.00 \\
\hline Marital status & & & & & & & \\
\hline Married & 24.8 & 1.00 & 1.00 & & & & 1.00 \\
\hline Unmarried & 37.6 & $1.67(1.23-2.27)$ & $1.36(0.98-1.89)$ & & & & $2.54(1.71-3.76)$ \\
\hline Job position & & & & & & & \\
\hline Low grade & 31.3 & $1.41(0.55-3.60)$ & $1.16(0.43-3.11)$ & & & & $1.02(0.36-2.91)$ \\
\hline Middle grade & 27.6 & $1.65(0.62-4.37)$ & $1.33(0.48-3.67)$ & & & & $1.28(0.44-3.74)$ \\
\hline High grade & 18.2 & 1.00 & 1.00 & & & & 1.00 \\
\hline Work hours & & & & & & & \\
\hline$<9 h$ & 25.0 & 1.00 & 1.00 & & & & 1.00 \\
\hline $9-11 \mathrm{~h}$ & 35.3 & $1.62(1.23-2.13)$ & 1.47(1.10-1.98) & & & & $1.11(0.79-1.57)$ \\
\hline$>11 \mathrm{~h}$ & 46.2 & $2.41(1.58-3.69)$ & $2.15(1.37-3.37)$ & & & & $1.33(0.80-2.22)$ \\
\hline Shift work & & & & & & & \\
\hline Yes & 36.1 & $1.51(1.17-1.96)$ & $1.34(1.01-1.77)$ & & & & $1.07(0.78-1.47)$ \\
\hline No & 26.1 & 1.00 & 1.00 & & & & 1.00 \\
\hline Control at work & & & & & & & \\
\hline Low & 37.5 & $2.00(1.44-2.77)$ & & $1.58(1.10-2.26)$ & & & $1.45(0.98-2.14)$ \\
\hline Intermediate & 30.6 & $1.44(1.04-2.00)$ & & $1.29(0.91-1.82)$ & & & $1.03(0.71-1.49)$ \\
\hline High & 23.0 & 1.00 & & 1.00 & & & 1.00 \\
\hline Demand at work & & & & & & & \\
\hline Low & 19.2 & 1.00 & & 1.00 & & & 1.00 \\
\hline Intermediate & 31.0 & $1.88(1.32-2.70)$ & & $2.20(1.50-3.22)$ & & & $1.37(0.89-2.10)$ \\
\hline High & 37.9 & $2.63(1.88-3.69)$ & & $2.82(1.97-4.03)$ & & & $1.49(0.97-2.30)$ \\
\hline Support at work & & & & & & & \\
\hline Low & 40.7 & $3.24(2.27-4.61)$ & & $2.05(1.37-3.06)$ & & & $1.97(1.29-3.02)$ \\
\hline Intermediate & 35.7 & $2.29(1.69-3.10)$ & & $1.83(1.33-2.51)$ & & & $1.89(1.34-2.66)$ \\
\hline High & 21.2 & 1.00 & & 1.00 & & & 1.00 \\
\hline Family-to-work & conflict & & & & & & \\
\hline Low & 23.0 & 1.00 & & & 1.00 & & 1.00 \\
\hline Intermediate & 22.1 & $1.01(0.64-1.60)$ & & & $0.76(0.46-1.25)$ & & $0.81(0.48-1.36)$ \\
\hline High & 40.2 & $2.89(2.15-3.89)$ & & & $2.01(1.44-2.79)$ & & $2.92(2.00-4.27)$ \\
\hline Work-to-family & conflict & & & & & & \\
\hline Low & 10.9 & 1.00 & & & 1.00 & & 1.00 \\
\hline Intermediate & 26.0 & $3.20(2.05-5.02)$ & & & $2.58(1.62-4.12)$ & & $2.38(1.46-3.906)$ \\
\hline High & 45.5 & $8.55(5.52-13.23)$ & & & $6.03(3.80-9.58)$ & & $4.82(2.89-8.04)$ \\
\hline
\end{tabular}


Table 4 The association between workplace social capital and depression in women (Continued)

\begin{tabular}{|c|c|c|c|c|c|c|c|}
\hline & & Age-adjusted ORs & Model 1 & Model 2 & Model 3 & Model 4 & Model 5 \\
\hline & $\begin{array}{l}\text { Prevalence of } \\
\text { depression(\%) }\end{array}$ & $(95 \% \mathrm{Cl})$ & $\begin{array}{l}\text { Work life condition } \\
(95 \% \mathrm{Cl})\end{array}$ & $\begin{array}{l}\text { Job stress } \\
(95 \% \mathrm{Cl})\end{array}$ & $\begin{array}{l}\text { Work-life balance } \\
(95 \% \mathrm{Cl})\end{array}$ & $\begin{array}{l}\text { Physical health } \\
(95 \% \mathrm{Cl})\end{array}$ & $\begin{array}{l}\text { Full adjusted } \\
(95 \% \mathrm{Cl})\end{array}$ \\
\hline Sleep ho & & & & & & & \\
\hline$<6 \mathrm{~h}$ & 43.5 & $2.23(1.65-3.02)$ & & & & $2.01(1.47-2.75)$ & $1.60(1.13-2.27)$ \\
\hline $6-8 \mathrm{~h}$ & 27.0 & 1.00 & & & & 1.00 & 1.00 \\
\hline$\geqq 9 \mathrm{~h}$ & 40.0 & $1.60(0.44-5.78)$ & & & & $1.52(0.40-5.75)$ & $1.40(0.33-5.91)$ \\
\hline Longstar & ness & & & & & & \\
\hline Yes & 33.3 & $1.47(1.08-2.00)$ & & & & $1.50(1.08-2.08)$ & $1.28(0.90-1.83)$ \\
\hline No & 29.6 & 1.00 & & & & 1.00 & 1.00 \\
\hline
\end{tabular}

Model 1 is adjusted for age, workplace social capital, and work life condition (marital status, job position, work hours, shift work)

Model 2 is adjusted for age, workplace social capital, and job stress (control at work, demand at work, support at work)

Model 3 is adjusted for age, workplace social capital, and work-life balance (family-to-work conflict, work-to-family conflict)

Model 4 is adjusted for age, workplace social capital, and physical health (sleep hours, longstanding illness)

Model 5 is adjusted for age, workplace social capital, work life condition, job stress, work-life balance, and physical health

unmarried was enhanced for both men and women after adjusting for all variables. Being married has been reported to contribute to greater mental stability [29]. It was considered that being married buffers the negative effect of lack of social capital at work and thereby reduces the risk of depression.

A difference was found between the genders for the variable of job stress. For men, control at work was an important factor in managing stress, whereas for women, job support was more significant. It was inferred that for men, an environment in which they could work under their own control was desirable for their mental health, while for women, an environment in which they could receive substantial work support from their colleagues at work was desirable.

When stratified by high and low workplace social capital, the ORs of long working hours and work-to-family conflict for depression were higher in the low workplace social capital group for both men and women. This suggests that workplace social capital may mitigate workrelated stress and reduce the risk of depression.

The association between depression and job status, job stress, and poor work-life balance was mitigated by workplace social capital, indicating that fostering workplace social capital may reduce or prevent the risk of depression. By gender, workplace social capital reduced the association of depression with low job position and low job support, particularly for men. For women, workplace social capital reduced the association between depression and being unmarried and working shifts. Because men and women may differ in their positions at work and at home, the roles they play, and their desired work environment, it is possible that a work environment that includes workplace social capital according to gender characteristics, i.e., a workplace where people understand and acknowledge each other, where men can get a high control at work, and where women can get actual job support, may be effective in maintaining and improving the mental health of workers.

There are several limitations to this study. First, this is a cross-sectional study and it is not possible to rule out the possibility of reverse causation, i.e., people with depression tend to feel that they have low workplace social capital. However, a prospective cohort study of Finnish public sector workers reported that there was a significant association between low workplace social capital and depression, even after adjusting for psychological distress at baseline [18]. Because of the complex relationship between depression and workplace social capital, work-life condition, job stress, work-life balance, and physical health, future longitudinal studies should be conducted to confirm these relationships. Second, there is a risk of common method bias in the data for this study [37]. Since multiple variables were taken from the same respondent in this study, it is possible that the subject was trying to maintain consistency and showed a higher correlation than the true correlation. Furthermore, subjects may have responded in a socially desirable manner due to their position as civil servants. Third, the subjects were civil servants, which may not be representative of the mental health and workplace social capital of the general workforce. The mean workplace social capital of the study's subjects (2.98 SD 0.68 points for men and 2.91 SD 0.68 points for women) was better than the national mean for both men and women (2.58 SD 0.76 points for men and 2.75 SD 0.76 points for women) [38], suggesting that they are a group with high workplace social capital. Even with these limitations, we believe the results of this large survey show that workplace social capital can independently reduce depression, even when adjusted for work and family stress. 
Table 5 Effect modification by workplace social capital on the association between depression and workplace and family stress

\begin{tabular}{|c|c|c|c|c|c|c|}
\hline & \multicolumn{3}{|l|}{ Men } & \multicolumn{3}{|l|}{ Women } \\
\hline & \multirow[b]{2}{*}{ All } & \multicolumn{2}{|c|}{ Stratified by Workplace social capital } & \multirow{3}{*}{$\begin{array}{l}\text { All } \\
\text { OR }(95 \% \mathrm{Cl})\end{array}$} & \multicolumn{2}{|c|}{ Stratified by Workplace social capital } \\
\hline & & High & Low & & High & Low \\
\hline & OR $(95 \% \mathrm{Cl})$ & OR $(95 \% \mathrm{Cl})$ & OR $(95 \% \mathrm{Cl})$ & & OR $(95 \% \mathrm{Cl})$ & OR $(95 \% \mathrm{Cl})$ \\
\hline \multicolumn{7}{|l|}{ Marital status } \\
\hline Married & 1.00 & 1.00 & 1.00 & 1.00 & 1.00 & 1.00 \\
\hline Unmarried & $1.92(1.44-2.56)$ & $1.79(1.26-2.54)$ & $2.39(1.32-4.33)$ & $1.67(1.23-2.27)$ & $1.55(1.06-2.27)$ & $1.38(0.77-2.48)$ \\
\hline \multicolumn{7}{|l|}{ Job position } \\
\hline Low grade & $1.73(1.19-2.51)$ & $1.30(0.83-2.04)$ & $1.56(0.70-3.47)$ & $1.41(0.55-3.60)$ & $1.66(0.47-5.91)$ & $0.29(0.03-2.95)$ \\
\hline Middle grade & $1.24(0.86-1.81)$ & $1.12(0.72-1.75)$ & $1.05(0.46-2.36)$ & $1.65(0.62-4.37)$ & $2.24(0.61-8.22)$ & $0.30(0.03-3.31)$ \\
\hline High grade & 1.00 & 1.00 & 1.00 & 1.00 & 1.00 & 1.00 \\
\hline \multicolumn{7}{|l|}{ Work hours } \\
\hline$<9 h$ & 1.00 & 1.00 & 1.00 & 1.00 & 1.00 & 1.00 \\
\hline $9-11 \mathrm{~h}$ & $1.33(1.03-1.71)$ & $1.27(0.93-1.73)$ & $1.91(1.12-3.34)$ & $1.62(1.23-2.13)$ & $1.49(1.07-2.08)$ & $2.05(1.19-3.54)$ \\
\hline$>11 \mathrm{~h}$ & $2.33(1.62-3.34)$ & $2.41(1.56-3.71)$ & $1.94(0.93-4.04)$ & $2.41(1.58-3.69)$ & $2.19(1.31-3.66)$ & $3.03(1.24-7.42)$ \\
\hline \multicolumn{7}{|l|}{ Shift work } \\
\hline Yes & $1.38(0.95-2.00)$ & $1.23(0.77-1.96)$ & $1.52(0.72-3.18)$ & $1.51(1.17-1.96)$ & $1.60(1.16-2.20)$ & $1.20(0.73-1.98)$ \\
\hline No & 1.00 & 1.00 & 1.00 & 1.00 & 1.00 & 1.00 \\
\hline \multicolumn{7}{|l|}{ Control at work } \\
\hline Low & $3.17(2.41-4.16)$ & $2.53(1.82-3.52)$ & $3.34(1.93-5.79)$ & $2.00(1.44-2.77)$ & $1.48(0.99-2.20)$ & $1.90(0.96-3.77)$ \\
\hline Intermediate & $1.78(1.35-2.35)$ & $1.60(1.16-2.21)$ & $2.22(1.24-3.97)$ & $1.44(1.04-2.00)$ & $1.28(0.88-1.87)$ & $1.68(0.80-3.51)$ \\
\hline High & 1.00 & 1.00 & 1.00 & 1.00 & 1.00 & 1.00 \\
\hline \multicolumn{7}{|l|}{ Demand at work } \\
\hline Low & 1.00 & 1.00 & 1.00 & 1.00 & 1.00 & 1.00 \\
\hline Intermediate & $1.64(1.24-2.18)$ & $1.61(1.14-2.27)$ & $1.75(0.98-3.11)$ & $1.88(1.32-2.70)$ & $1.72(1.12-2.65)$ & $2.89(1.41-5.92)$ \\
\hline High & $2.33(1.77-3.08)$ & $2.23(1.60-3.12)$ & $2.01(1.16-3.48)$ & $2.63(1.88-3.69)$ & $2.23(1.48-3.36)$ & $3.63(1.91-6.88)$ \\
\hline \multicolumn{7}{|l|}{ Support at work } \\
\hline Low & $2.05(1.55-2.73)$ & $1.20(0.83-1.74)$ & $1.55(0.82-2.93)$ & $3.24(2.27-4.61)$ & $2.29(1.42-3.70)$ & $1.48(0.72-3.02)$ \\
\hline Intermediate & $1.23(0.94-1.62)$ & $1.20(0.88-1.63)$ & $0.77(0.39-1.53)$ & $2.29(1.69-3.10)$ & $2.11(1.49-2.99)$ & $1.43(0.69-2.96)$ \\
\hline High & 1.00 & 1.00 & 1.00 & 1.00 & 1.00 & 1.00 \\
\hline \multicolumn{7}{|c|}{ Family-to-work conflict } \\
\hline Low & 1.00 & 1.00 & 1.00 & 1.00 & 1.00 & 1.00 \\
\hline Intermediate & $1.70(1.18-2.46)$ & $2.10(1.37-3.23)$ & $0.70(0.33-1.48)$ & $1.01(0.64-1.60)$ & $1.19(0.68-2.09)$ & $0.58(0.25-1.35)$ \\
\hline High & $5.16(3.97-6.71)$ & 4.86(3.54-6.69) & $3.92(2.32-6.61)$ & $2.89(2.15-3.89)$ & $3.14(2.17-4.54)$ & $2.50(1.41-4.42)$ \\
\hline \multicolumn{7}{|c|}{ Work-to-family conflict } \\
\hline Low & 1.00 & 1.00 & 1.00 & 1.00 & 1.00 & 1.00 \\
\hline Intermediate & $2.70(1.91-3.81)$ & $2.57(1.71-3.86)$ & $2.64(1.30-5.35)$ & $3.20(2.05-5.02)$ & $2.78(1.67-4.60)$ & $3.29(1.11-9.80)$ \\
\hline High & $8.15(5.81-11.43)$ & $6.58(4.42-9.78)$ & 10.89(5.27-22.48) & $8.55(5.52-13.23)$ & $6.56(4.03-10.69)$ & $11.54(3.87-34.40)$ \\
\hline \multicolumn{7}{|l|}{ Sleep hours } \\
\hline$<6 h$ & $2.63(2.01-3.45)$ & $2.39(1.73-3.32)$ & $3.81(2.06-7.04)$ & $2.23(1.65-3.02)$ & $2.48(1.70-3.60)$ & $1.30(0.74-2.29)$ \\
\hline $6-8 \mathrm{~h}$ & 1.00 & 1.00 & 1.00 & 1.00 & 1.00 & 1.00 \\
\hline$\geqq 9 \mathrm{~h}$ & $2.24(0.74-6.74)$ & $2.24(0.57-8.78)$ & $1.87(0.25-13.94)$ & $1.60(0.44-5.78)$ & $2.51(0.55-11.58)$ & $0.42(0.04-4.85)$ \\
\hline \multicolumn{7}{|c|}{ Longstanding illness } \\
\hline Yes & $1.81(1.43-2.29)$ & $1.44(1.07-1.92)$ & $3.11(1.92-5.05)$ & $1.47(1.08-2.00)$ & $1.57(1.08-2.29)$ & $1.43(0.77-2.68)$ \\
\hline No & 1.00 & 1.00 & 1.00 & 1.00 & 1.00 & 1.00 \\
\hline
\end{tabular}

$O R$ odds ratio for depression adjusting for age, $\mathrm{Cl}$ confidence interval 


\section{Conclusions}

Workplace social capital for both men and women showed independent associations between depression and workplace variables; however, workplace social capital reduces the association between depression and work-life condition, job stress, work-life balance, and physical health. Although future longitudinal studies are needed to ascertain the relationship between depression and workplace social capital, work situation, work and family stress, and physical health, it may be possible to reduce or prevent the risk of depression in workers by creating a working environment that fosters workplace social capital.

\section{Abbreviations}

SES: Socioeconomic status; Cl: Confidence interval; OR: Odds ratio

\section{Acknowledgements}

We would like to express our deepest gratitude to all the civil servants who participated in this study and to the local governments that cooperated with us.

\section{Authors' contributions}

NN, MS, TT, and MY contributed to the study design, acquisition of data, analysis and interpretation of data, and preparation of the manuscript. All authors read and approved the final manuscript.

\section{Funding}

This study was supported by grants from the Ministry of Health, Labour and Welfare, the Japanese Society for the Promotion of Science, the Universe Foundation (98.04.017), the Daiwa Anglo-Japanese Foundation (03/2059), and the Great Britain Sasakawa Foundation (2551). The funding bodies were not involved in the design, conduct, interpretation or analysis of the study and did not review or approve the manuscript.

\section{Availability of data and materials}

The datasets analyzed during the current study are available from the corresponding author on reasonable request.

\section{Declarations}

\section{Ethics approval and consent to participate}

The study was conducted with the approval of the Ethics Review Committee of the University of Toyama, and the study was carried out in accordance with the Helsinki Declaration. All subjects voluntarily participated in this study and signed informed consent forms before enrollment.

\section{Consent for publication}

Not applicable.

\section{Competing interests}

The authors declare that they have no competing interests.

Received: 10 January 2021 Accepted: 1 April 2021

Published online: 14 April 2021

\section{References}

1. Health, Labour and Welfare Statistics Association. Journal of health and welfare statistics 2020/2021. Tokyo: Health, Labour and Welfare Statistics Association; 2020. (in Japanese)

2. WHO. Mental health. 2020. https://www.who.int/mental_health/resources/ preventingsuicide/en/. Accessed 15 Nov 2020.

3. Labour Policy Research and Training Institute. Survey on Mental Health Measures in the Workplace. https://www.jil.go.jp/institute/research/2012/ documents/0100.pdf. Accessed 15 Nov 2020. (in Japanese).

4. Japan local government employee safety \& health association. Summary of the Current Status of Health of Local Government Officials in 2020. http:// www.jalsha.or.jp/tyosa/result. Accessed 11 Mar 2021. (in Japanese).
5. Sekine M, Chandola T, Martikainen P, Marmot M, Kagamimori S. Sex differences in physical and mental functioning of Japanese civil servants: explanations from work and family characteristics. Soc Sci Med. 2010;71(12): 2091-9. https://doi.org/10.1016/j.socscimed.2010.09.031.

6. Grynderup MB, Mors O, Hansen AM, Andersen JH, Bonde JB, Kargaard A, et al. A two-year follow-up study of risk of depression according to workunit measures of psychological demands and decision latitude. Scand J Work Environ Health. 2012;38(6):527-36. https://doi.org/10.5271/sjweh.3316.

7. Grynderup MB, Mors O, Hansen AM, Andersen JH, Bonde JB, Kargaard A, et al. Work-unit measures of organisational justice and risk of depression-a 2-year cohort study. Occup Environ Med. 2013;70(6):380-5. https://doi.org/1 0.1136/oemed-2012-101000.

8. Grynderup MB, Kolstad HA, Mikkelsen S, Andersen JH, Bonde JP, Buttenschon HN, et al. A two-year follow-up study of salivary cortisol concentration and the risk of depression. Psychoneuroendocrinology. 2013; 38(10):2042-50. https://doi.org/10.1016/j.psyneuen.2013.03.013.

9. Tatsuse T, Sekine M. Job dissatisfaction as a contributor to stress-related mental health problems among Japanese civil servants. Ind Health. 2011;51: 307-18.

10. Tatsuse T, Sekine M, Yamada M. The contributions made job satisfaction and psychosocial stress to the development and persistence of depressive symptoms a 1-year prospective study. J Occup Environ Med. 2019;61(3): 190-6. https://doi.org/10.1097/JOM.0000000000001491.

11. Aida J, Hanibuchi T, Nakade M, Hirai H, Osaka K, Kondo K. The different effects of vertical social capital and horizontal social capital on dental status: a multilevel analysis. Soc Sci Med. 2009;69:512-8.

12. Meng A, Clausen T, Borg V. The association between team-level social capital and individual-level work engagement: differences between subtypes of social capital and the impact of intra-team agreement. Scand J Psychol. 2018;59(2):198-205. https://doi.org/10.1111/sjop.12435.

13. Clausen T, Meng A, Borg V. Does social capital in the workplace predict job performance, work engagement, and psychological well-being? A prospective analysis. JOEM. 2019;61(10):800-5. https://doi.org/10.1097/JOM. 0000000000001672

14. Fujita S, Kawakami N, Ando E, Inoue A, Tsuno K, Kurioka S, et al. The association of workplace social capital with work engagement of employees in health care settings a multilevel cross-sectional analysis. JOEM. 2016;58(3): 265-71. https://doi.org/10.1097/JOM.0000000000000605.

15. Firouzbakht M, Tirger A, Oksanen T, Kawachi I, Hajian-Tilaki K, Nikpour M, et al. Workplace social capital and mental health: a cross-sectional study among Iranian workers. BMC Public Health. 2018;18(1):794. https://doi.org/1 0.1186/s12889-018-5659-3.

16. Gao J, Weaver SR, Dai J, Jia Y, Liu X, Jin K, et al. Work place social capital and mental health among Chinese employees: a multi-level, cross-sectional study. PLoS One. 2014;9(1):e85005. https://doi.org/10.1371/journal.pone. 0085005.

17. Inoue A, Kawakami N, Eguchi H, Tsutsumi A. Buffring effect of workplace social capital on the association of job insecurity with psychological distress in Japanese employees: a-cross-sectional study. J Occup Health. 2016;58(5): 460-9. https://doi.org/10.1539/joh.16-0129-OA

18. Kouvonen A, Oksanen T, Vahtera J, Stafford M, Wilkinson R, Schineider J, et al. Low workplace social capital as a predictor of depression the Finnish public sector study. Am J Epidemiol. 2008;167(10):1143-51. https://doi.org/1 0.1093/aje/kwn067.

19. Oksanen T, Kouvonen A, Vahtera J, Virtanen M, Kivimaki M. Prospective study of workplace social capital and depression: are vertical and horizontal components equally important? J Epidemiol Community Health. 2010;64(8): 684-9. https://doi.org/10.1136/jech.2008.086074.

20. Doi Y, Minowa M. Gender differences in excessive daytime sleepiness among Japanese workers. Soc Sci Med. 2003;56(4):883-94. https://doi.org/1 0.1016/S0277-9536(02)00089-8.

21. Martikainen $P$, Lahelma $E$, Marmot $M$, Sekine $M$, Nishi N, Kagamimori S. A comparison of socioeconomic differences in physical functioning and perceived health among male and female employees in Britain, Finland and Japan. Soc Sci Med. 2004;54:1287-95.

22. Sekine M, Tatsuse T, Kagamimori S, Chandola T, Cable N, Marmot M, et al. Sex inequalities in physical and mental functioning of British, Finnish, and Japanese civil servants: role of job demand, control and work hours. Soc Sci Med. 2011;73(4):595-603. https://doi.org/10.1016/j.socscimed.2011.06.026.

23. Verbrugge LM. Gender and health: an update on hypotheses and evidence. J Health Soc Behav. 1985;26(3):156-82. https://doi.org/10.2307/2136750. 
24. Sekine M, Chandola T, Martikainen P, Marmot M, Kagamimori S. Work and family characteristics as determinants of socioeconomic and sex inequalities in sleep: the Japanese civil servants study. Sleep. 2006;29(2):206-16. https:// doi.org/10.1093/sleep/29.2.206

25. Sekine M, Tatsuse T, Cable N, Chandola T, Marmot M, Lallukka T, et al. Socioeconomic and gender inequalities in difficulty falling asleep of British, Finnish, and Japanese civil servants: roles of job strain, work hours and work-family conflicts. J Sleep Res. 2012;21:154-5.

26. Karasek RA. Job demands, job decision latitude and mental strain: Implications for job design. Adm Sci Q. 1979;24(2):285-308. https://doi.org/1 $0.2307 / 2392498$

27. Chandola T, Martikainen P, Bartley M, Lahelma E, Marmot M, Sekine M, et al. Does conflict between home and work explain the effect of multiple roles on mental health? A comparative study of Finland, Japan, and the UK. Int J Epidemiol. 2004:33(4):884-93. https://doi.org/10.1093/ije/dyh155.

28. Radloff LS. The CES-D scale: a self-report depression scale for research in the general population. Appl Psychol Meas. 1977;1(3):385-401. https://doi.org/1 0.1177/014662167700100306.

29. Wada K, Tanaka K, Theriault G, Satoh T, Mimura M, Miyaoka H, et al. Validity of the center for epidemiologic studies depression scale as a screening instrument of major depressive disorder among Japanese workers. Am J Ind Med. 2007;50(1):8-12. https://doi.org/10.1002/ajim.20403.

30. Health, Labour and Welfare. Results of the FY 2009-2011 Science Research Grant (Comprehensive Research on Occupational Safety and Health) "Survey on Methods of Primary Prevention of Mental Health Problems among Workers". 2011. https://www.mhlw.go.jp/file/05-Shingikai-11201000Roudoukijunkyoku-Soumuka/0000050925.pdf. Accessed 15 Nov 2020. (in Japanese).

31. Inoue A, Kawakami N, Shimomitsu T, Tsutsumi A, Haratani T, Yoshikawa T, et al. Development of a short questionnaire to measure an extended set of job demands, job resources, and positive health outcomes: the new brief job stress questionnaire. Ind Health. 2014;52(3):175-89. https://doi.org/10.24 86/indhealth.2013-0185.

32. Inoue A, Kawakami N, Shimomitsu T, Tsutsumi A, Haratani T, Yoshikawa T, et al. Development of short version of the new brief job stress questionnaire. Ind Health. 2014;52(6):535-40. https://doi.org/10.2486/indhea Ith.2014-0114.

33. Hosmer DW Jr, Lemeshow S, Sturdevant RX. Model-Building Strategies and Methods for Logistic Regression. In: Applied logistic regression. 3rd ed. New Jersey: Wiley; 2013. p. 89-151.

34. Sekine $M$, Chandora $T$, Martikainen $P$, Marmot $M$, Kagamimori S. Socioeconomic inequalities in physical and mental functioning of Japanese civil servants: explanations from work and family characteristics. Soc Sci Med. 2006;63(2):430-45. https://doi.org/10.1016/j.socscimed.2006.01.020.

35. Sekine M, Chandora T, Martikainen P, Marmot M, Kagamimori S. Sex inequalities in physical and mental functioning of British, Finnish, and Japanese civil servants: role of job demand, control and work hours. Soc Sci Med. 2009;69(10):1417-25. https://doi.org/10.1016/j.socscimed.2009.08.022

36. Fujimura $Y$, Sekine $M$, Tatsuse $T$. Sex differences in factors contributing to family-to-work and work-to-family conflict in Japanese civil servants. J Occup Health. 2014;56(6):485-97. https://doi.org/10.1539/joh.14-0045-OA.

37. Podsakoff PM, Mackenzie SB, Lee JY, Podsakoff NP. Common method biases in behavioral research: a critical review of the literature and recommended remedies. J Appl Psychol. 2003;88(5):879-903. https://doi.org/10.1037/00219010.88.5.879

38. Department of Mental Health, Graduate School of Medicine, University of Tokyo. National average data for the current and new Occupational Stress Brief Questionnaire scales: http://mental.m.u-tokyo.ac.jp/jstress/. Accessed 15 Nov 2020. (in Japanese).

\section{Publisher's Note}

Springer Nature remains neutral with regard to jurisdictional claims in published maps and institutional affiliations.

Ready to submit your research? Choose BMC and benefit from:

- fast, convenient online submission

- thorough peer review by experienced researchers in your field

- rapid publication on acceptance

- support for research data, including large and complex data types

- gold Open Access which fosters wider collaboration and increased citations

- maximum visibility for your research: over $100 \mathrm{M}$ website views per year

At BMC, research is always in progress.

Learn more biomedcentral.com/submissions 